\title{
Analisis Karakteristik Kecelakaan di Ruas Jalan Gadjah Mada Kabupaten Jember
}

\author{
Tiara Ayu Rahmawaty ${ }^{1}$, Willy Kriswardhana*², Wiwik Yunarni Widiarti ${ }^{3}$ \\ Sonya Sulistyono ${ }^{4}$ \\ 1,2,3,4 Jurusan Teknik Sipil, Fakultas Teknik, Universitas Jember, Jl. Kalimantan 37 Jember, Indonesia \\ E-mail: willy.teknik@unej.ac.id
}

Received 07 Februari 2020; Reviewed 22 April 2020; Accepted 05 Juni 2020

Journal Homepage: http://jurnal.borneo.ac.id/index.php/borneoengineering

DOI: https://doi.org/10.35334/be.v4i1.1272

\begin{abstract}
Gadjah Mada Road is one of the main roads in the Jember and is an urban road that has high activity. Therefore, it has a history of traffic accidents. The purpose of this study was to determine the characteristics of accidents at the KFC-Sentot Prawirodirdjo intersection and Sentot Prawirodirdjo-Argopuro intersection, to determine the EAN (Equivalent Accident Number) value, and the accident rate. Accident characteristics were analyzed based on the number of accidents obtained from the Integrated Road Safety Management System (IRSMS) on weekdays and weekends, EAN value was calculated to estimate the accident weight, and accident rate to determine the level of accident vulnerability. From the analysis, the results obtained from 2017-2018 in the KFC-Sentot Prawirodirdjo intersection have 87 accidents and the Sentot PrawirodirdjoArgopuro intersection in 2014-2018 there were 228 accidents. Most of the accident victims at the KFCSimpang Sentot Prawirodirdjo intersection were minor injuries and material losses. Vehicles that often involved in accidents were motorcycles. The time of the accident that often occurs was the night (17.0121.00). The dominant type of accident is a crash when overtaking from the right. Furthermore, for the Sentot Prawirodirdjo-Argopuro intersection, most accident victims were minor injuries and material losses. The vehicle that is often involved is a motorcycle. The time of the most dominant accident is morning (05.0109.00), and the type of accident that dominates is crash when overtaking from the right.
\end{abstract}

Keywords: gadjah mada street, characteristics of accidents, EAN, accident rate

\begin{abstract}
Abstrak
Jalan Gadjah Mada merupakan salah satu jalur utama Kabupaten Jember dan merupakan jalan perkotaan yang memiliki aktivitas kegiatan cukup tinggi sehingga memiliki cukup banyak riwayat kecelakaan lalu lintas. Tujuan penelitian ini adalah untuk mengetahui karakteristik kecelakaan pada ruas KFC-Simpang Sentot Prawirodirdjo dan Simpang Sentot Prawirodirdjo-Simpang Argopuro, untuk mengetahui nilai EAN (Equivalent Accident Number), dan nilai tingkat kecelakaan. Karakteristik kecelakaan dianalisis berdasarkan jumlah kecelakaan yang didapatkan dari IRSMS (Integrated Road Safety Management System) pada weekend dan weekend, nilai EAN dihitung untuk memperkirakan bobot kejadian kecelakaan dan tingkat kecelakaan untuk mengetahui tingkat kerawanan kecelakaan. Dari analisis didapatkan hasil sepanjang tahun 2017-2018 pada ruas KFC-Simpang Sentot Prawirodirdjo terdapat 87 kecelakaan dan pada Simpang Sentot Prawirodirdjo-Simpang Argopuro sepanjang tahun 2014-2018 terdapat 228 kecelakaan. Korban kecelakaan pada ruas KFC-Simpang Sentot Prawirodirdjo yang paling banyak adalah luka ringan dan kerugian materi. Kendaraan yang sering terlibat kecelakaan adalah sepeda motor. Waktu kejadian kecelakaan yang sering terjadi adalah malam hari (17.01-21.00). Tipe kecelakaan yang mendominasi adalah tabrakan saat menyalip dari kanan. Selanjutnya untuk Simpang Sentot Prawirodirdjo-Simpang Argopuro korban kecelakaan yang paling banyak adalah luka ringan dan kerugian materi. Kendaraan yang sering terlibat adalah sepeda motor. Waktu kejadian kecelakaan yang paling dominan adalah pagi hari, dan tipe kecelakaan yang mendominasi adalah tabrakan saat saat menyalip dari kanan.
\end{abstract}

Kata kunci: Jalan gadjah mada, Karakteristik kecelakaan, EAN, Tingkat kecelakaan 


\section{Pendahuluan}

Keselamatan jalan raya di era yang semakin modern ini merupakan salah satu masalah yang penting untuk diperhatikan. Peningkatan jumlah kendaraan yang beroperasi di jalan tidak seimbang dengan peningkatan kesadaran dalam berkendara sehingga semakin memperparah masalah transportasi (Arifin et al., 2019). Dalam penelitian (Sugiyanto \& Santi, 2015) untuk mengubah persepsi dan paradigma tentang keselamatan jalan harus dilakukan melalui pendidikan keselamatan dan sosialisasi kepada masyarakat sejak dini untuk menumbuhkan rasa disiplin lalu lintas. Semakin muda usia seseorang, maka semakin tinggi probabilitasnya dalam melanggar batas kecepatan maksimum (Kriswardhana et al., 2019). Tingginya insiden kecelakaan lalu lintas mendasari Organisasi Kesehatan Dunia (World Health Organization) menyatakan bahwa setiap tahun tercatat 1,35 juta orang meninggal dunia karena kecelakaan lalu lintas di dunia. Hal ini diperkirakan pada tahun 2020 kecelakaan lalu lintas akan menjadi penyebab utama kematian nomor tiga setelah penyakit jantung (Direktorat Keselamatan Transportasi Darat, 2007).

Penelitian (Sugiyanto, 2010) menyatakan bahwa dengan tingkat kecelakaan lalu lintas jalan yang tinggi, kerugian yang ditimbulkan juga sangat tinggi baik berupa korban nyawa ataupun harta benda. Dalam sebuah penelitian, penyebab utama kecelakaan lalu lintas adalah kurang disiplinnya pengguna jalan (Zanuardi \& Suprayitno, 2018). Penelitian lain menyebutkan bahwa faktor utama yang menjadi penyebab semakin tingginya jumlah kecelakaan lalu lintas yaitu pertumbuhan kepemilikan kendaraan bermotor terutama jenis sepeda motor yang diikuti dengan mobil penumpang (Sugiyanto et al., 2014). Berdasarkan penelitian di Jalan Pantura Surabaya-Tuban, sepeda motor merupakan kendaraan yang sering terlibat dalam kecelakaan lalu lintas yaitu sebesar 63,21\% (Hayati et al., 2016). Menurut penelitian (Indriastuti et al., 2011) pada ruas Jalan Ahmad Yani Surabaya dengan pendekatan EAN, lokasi rawan kecelakaan dengan nilai tertinggi yaitu 90 dapat diketahui yaitu di Royal Plaza dengan kendaraan yang dominan terlibat adalah kendaraan roda dua. Penyebab kecelakaan lalu lintas terjadi beraneka ragam, diantaranya yaitu kelalaian pengendara kendaraan itu sendiri (human error) (Carina, 2014). Dalam penelitian ini dijelaskan karakteristik kecelakaan, EAN, dan tingkat kecelakaan berdasarkan weekday, weekend pada arah kota dan luar kota sehingga didapatkan hasil yang lebih detail.

Di Jalan Gadjah Mada Kabupaten Jember berdasarkan data IRSMS (Integrated Road Safety Management System) terdapat cukup banyak riwayat kecelakaan lalu lintas yang tersebar pada ruas KFC-Simpang Sentot Prawirodirdjo dan Simpang Sentot Prawirodirdjo-Simpang Argopuro. Banyaknya kejadian kecelakaan ini mendasari penelitian dilakukan dengan tujuan untuk menganalisis karakteristik kecelakaan di ruas Jalan Gadjah Mada Kabupaten Jember.

\section{Metode Penelitian}

Lokasi penelitian ini di Jalan Gadjah Mada Kabupaten Jember yaitu pada ruas KFC-Simpang Sentot Prawirodirdjo dan Simpang Sentot Prawirodirdjo-Simpang Argopuro yang dapat dilihat pada gambar berikut.

Tahapan yang dilakukan dalam penelitian ini adalah:

1. Studi literatur, yaitu untuk melakukan tinjauan terkait dengan klasifikasi karakteristik kecelakaan, EAN, dan tingkat kecelakaan.

2. Pengumpulan data. Pengumpulan data meliputi data primer yang merupakan data yang langsung didapatkan di lapangan dan data sekunder yang merupakan data yang didapatkan dari sumber. Data primer dan data sekunder dalam penelitian ini yaitu: 
a. Data primer meliputi survei lokasi untuk menentukan segmen jalan pada lokasi penelitian, dan survei volume lalu lintas yang dilakukan dari counting video yang didapatkan dari Dinas Perhubungan Kabupaten Jember. Dari volume lalu lintas ini akan diolah sampai mendapatkan volume lalu lintas harian rata-rata dan selanjutnya hasil dari volume lalu lintas rata-rata digunakan untuk menghitung nilai tingkat kecelakaan.

b. Data sekunder yaitu berupa data kecelakaan lalu lintas yaitu IRSMS (Integrated Road Safety Management System) yang didapatkan dari Korlantas Mabes Polri. Dari data kecelakaan ini didapatkan jumlah kecelakaan, klasifikasi korban, tipe kendaraan, waktu kejadian kecelakaan, dan tipe kecelakaan.

3. Analisis data, yaitu meliputi analisis karakteristik kecelakaan yang dipilih berdasarkan karakteristik yang paling menonjol, EAN akan dihitung untuk memperkirakan bobot kejadian kecelakaan dan tingkat kecelakaan untuk mengetahui tingkat kerawanan kecelakaan pada ruas jalan yang diteliti.

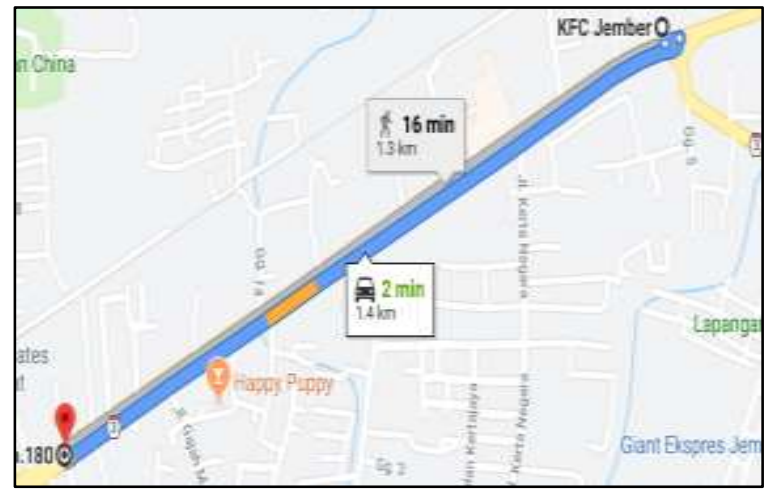

Gambar 1. KFC-Simpang Sentot Prawirodirdjo

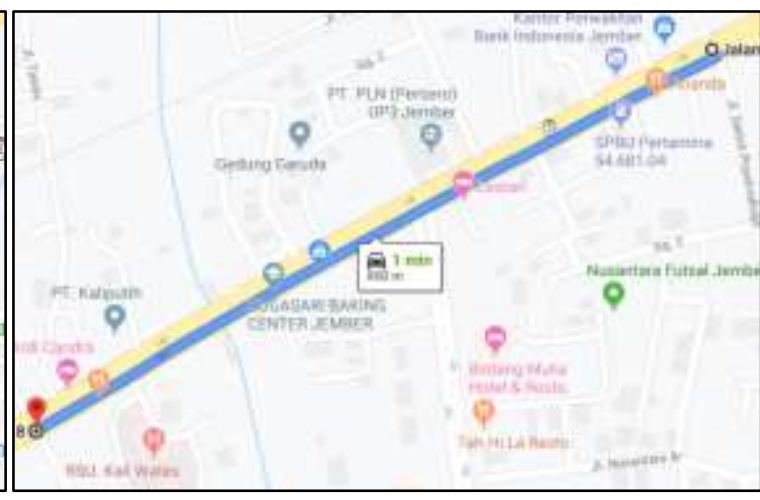

Gambar 2.Simpang Sentot PrawirodirdjoSimpang Argopuro

\section{Hasil dan Pembahasan}

\subsection{EAN (Equivalent Accident Number)}

Equivalent Accident Number (EAN) merupakan angka kecelakaan yang didasarkan atas biaya kecelakaan dengan melakukan pembobotan kejadian kecelakaan (Departemen Permukiman dan Prasarana Wilayah, 2004). Dalam penelitian (Feryanti, 2019) menyatakan bahwa Metode EAN atau Angka Ekivalen Kecelakaan lebih unggul dari tiga metode yang digunakan dalam penelitian yaitu Metode Angka Ekivalen Kecelakaan, Metode Departemen Perhubungan dan Metode KSI. Dalam penelitian ini, metode yang digunakan untuk mengetahui bobot nilai kecelakaan yaitu dengan Metode EAN dengan menggunakan perbandingan sebagai berikut.

$$
\mathrm{F}: \mathrm{I}: \mathrm{DO}=12: 3: 1
$$

dimana,

$$
\begin{array}{ll}
\mathrm{F} & =\text { kecelakaan fatal } \\
\mathrm{I} & =\text { korban luka } \\
\mathrm{DO} & =\text { kerugian materi }
\end{array}
$$

Hasil dari perhitungan nilai EAN dapat dilihat pada tabel berikut. 
Tabel 1. Nilai EAN pada ruas KFC-Simpang Sentot Prawirodirdjo

\begin{tabular}{|c|c|c|c|c|c|c|c|c|c|c|}
\hline \multirow[t]{2}{*}{ Ruas Jalan } & \multirow[t]{2}{*}{$\begin{array}{l}\text { Weekday/ } \\
\text { Weekend }\end{array}$} & \multirow[t]{2}{*}{ Arah } & \multicolumn{3}{|c|}{$\begin{array}{c}\text { Jumlah } \\
\text { Kecelakaan } \\
\mathbf{2 0 1 7 - 2 0 1 8} \\
\end{array}$} & \multicolumn{3}{|c|}{ Nilai EAN } & \multirow[t]{2}{*}{$\begin{array}{l}\text { Total } \\
\text { EAN }\end{array}$} & \multirow[t]{2}{*}{$(\%)$} \\
\hline & & & $\mathbf{F}$ & I & DO & $\mathbf{F}$ & $\mathbf{I}$ & DO & & \\
\hline \multirow{5}{*}{$\begin{array}{c}\text { KFC- } \\
\text { Simpang } \\
\text { Sentot } \\
\text { Prawirodirdjo }\end{array}$} & \multirow{2}{*}{ Weekday } & Kota & 1 & 7 & 8 & 12 & 21 & 8 & 41 & 47,13 \\
\hline & & Luar Kota & - & 6 & 8 & - & 18 & 8 & 26 & 29,89 \\
\hline & \multirow{2}{*}{ Weekend } & Kota & - & 1 & 1 & - & 3 & 1 & 4 & 4,60 \\
\hline & & Luar Kota & - & 4 & 4 & - & 12 & 4 & 16 & 18,39 \\
\hline & Total & & 1 & 18 & 21 & 12 & 54 & 21 & 87 & 100 \\
\hline
\end{tabular}

Dari Tabel 1 didapatkan hasil bahwa bobot kecelakaan yang paling besar pada ruas KFC-Simpang Sentot Prawirodirdjo adalah weekday arah kota dengan persentase 47,13\%.

Tabel 2. Nilai EAN pada Simpang Sentot Prawirodirdjo-Simpang Argopuro

\begin{tabular}{|c|c|c|c|c|c|c|c|c|c|c|}
\hline \multirow[t]{2}{*}{ Ruas Jalan } & \multirow[t]{2}{*}{$\begin{array}{l}\text { Weekday/ } \\
\text { Weekend }\end{array}$} & \multirow[t]{2}{*}{ Arah } & \multicolumn{3}{|c|}{$\begin{array}{c}\text { Jumlah } \\
\text { Kecelakaaan } \\
\text { 2014-2018 } \\
\end{array}$} & \multicolumn{3}{|c|}{ Nilai EAN } & \multirow[t]{2}{*}{$\begin{array}{l}\text { Total } \\
\text { EAN }\end{array}$} & \multirow[t]{2}{*}{$(\%)$} \\
\hline & & & $\mathbf{F}$ & I & DO & $\mathbf{F}$ & I & DO & & \\
\hline \multirow{5}{*}{$\begin{array}{c}\text { Simpang } \\
\text { Sentot } \\
\text { Prawirodirdjo- } \\
\text { Simpang } \\
\text { Argopuro }\end{array}$} & \multirow{2}{*}{ Weekday } & Kota & 2 & 19 & 10 & 24 & 57 & 10 & 97 & 42,54 \\
\hline & & Luar Kota & 3 & 8 & 11 & 36 & 24 & 11 & 71 & 31,14 \\
\hline & \multirow{2}{*}{ Weekend } & Kota & 1 & 3 & 6 & 12 & 9 & 6 & 27 & 11,84 \\
\hline & & Luar Kota & 1 & 5 & 6 & 12 & 15 & 6 & 33 & 14,47 \\
\hline & Total & & 7 & 35 & 33 & 84 & 105 & 33 & 228 & 100 \\
\hline
\end{tabular}

Hasil nilai EAN berdasarkan bobot kecelakaan yang paling besar pada Tabel 2 yaitu Simpang Sentot Prawirodirdjo-Simpang Argopuro adalah weekday arah kota dengan persentase 42,54\%. Sehingga dapat disimpulkan bahwa bobot nilai kecelakaan yang paling tinggi untuk ruas KFCSimpang Sentot Prawirodirdjo dan Simpang Sentot Prawirodirdjo-Simpang Argopuro adalah pada weekday arah kota.

\subsection{Tingkat Kecelakaan}

Tingkat kecelakaan dihitung untuk mengetahui tingkat kerawanan kecelakaan lalu lintas yang didapatkan dari rumus berikut.

$\mathrm{Tk}=\frac{F k \times 10^{8}}{L H R \operatorname{x} \times \mathbf{L} \times 365}, 100 \mathrm{JPKP}$

dengan,

$\mathrm{Tk} \quad=$ tingkat kecelakaan

$\mathrm{Fk} \quad=$ frekuensi kecelakaan

LHRt $=$ volume lalu lintas rata-rata

$\mathrm{N} \quad=$ tahun data

$\mathrm{L} \quad=$ panjang ruas jalan

Maksud dari 100 JPKP adalah satuan tingkat kecelakaan (Kecelakaan Per Seratus Juta Perjalanan Kendaraan Per Kilometer)

Volume lalu lintas rata-rata dilakukan dari counting video yang didapatkan dari Dinas Perhubungan Kabupaten Jember dan didapatkan hasil sebagai berikut. 
Tabel 3. Volume Lalu Lintas Rata-Rata Pada Ruas KFC-Simpang Sentot Prawirodirdjo

\begin{tabular}{cccccc}
\hline \multirow{2}{*}{ Segmen } & \multirow{2}{*}{$\begin{array}{c}\text { Weekday/ } \\
\text { Weekend }\end{array}$} & \multirow{2}{*}{ Arah } & \multicolumn{3}{c}{ Volume Lalu Lintas Rata- } \\
\cline { 4 - 5 } & & Rata & \multirow{2}{*}{ Jumlah } \\
\cline { 3 - 5 } & \multirow{2}{*}{ Weekday } & Kota & 2135 & 997 & 3132 \\
& \multirow{2}{*}{ Luar Kota } & 1863 & 816 & 2679 \\
Simpang Sentot & & Kota & 2176 & 981 & 3158 \\
Prawirodirdjo- & \multirow{2}{*}{ Weekend } & Luar Kota & 3907 & 871 & 4778 \\
& & Luar &
\end{tabular}

Tabel 4. Volume Lalu Lintas Rata-Rata Pada Simpang Sentot Prawirodirdjo-Simpang Argopuro

\begin{tabular}{cccccc}
\hline \multirow{2}{*}{ Segmen } & \multirow{2}{*}{$\begin{array}{c}\text { Weekday/ } \\
\text { Weekend }\end{array}$} & \multirow{2}{*}{ Arah } & \multicolumn{3}{c}{ Volume Lalu Lintas Rata- } \\
\cline { 4 - 5 } & & Rata & \multirow{2}{*}{ Jumlah } \\
\cline { 4 - 5 } & \multirow{2}{*}{ Weekday } & Kota & 2768 & 774 & 3542 \\
& \multirow{2}{*}{ Luar Kota } & 1790 & 1002 & 2792 \\
Segmen 2-Simpang & \multirow{2}{*}{ Weekend } & Kota & 2107 & 823 & 2930 \\
Sentot Prawirodirdjo- & Luar Kota & 1993 & 963 & 2956 \\
\hline
\end{tabular}

Data frekuensi kecelakaan atau banyaknya kecelakaan lalu lintas didapatkan dari data IRSMS (Integrated Road Safety Management System) yang dapat dilihat pada tabel berikut.

Tabel 5. Jumlah Kecelakaan Pada Ruas KFC-Simpang Sentot Prawirodirdjo

\begin{tabular}{|c|c|c|c|c|c|}
\hline \multirow{2}{*}{ Ruas Jalan } & \multirow{2}{*}{$\begin{array}{l}\text { Weekday/ } \\
\text { Weekend }\end{array}$} & \multirow{2}{*}{ Arah } & \multicolumn{2}{|c|}{ Jumlah Kecelakaan } & \multirow{2}{*}{$\sum$ Laka } \\
\hline & & & 2017 & 2018 & \\
\hline \multirow{4}{*}{$\begin{array}{l}\text { KFC-Simpang Sentot } \\
\text { Prawirodirdjo }\end{array}$} & \multirow[b]{2}{*}{ Weekday } & Kota & 5 & 3 & 8 \\
\hline & & $\begin{array}{l}\text { Luar } \\
\text { Kota }\end{array}$ & 1 & 6 & 7 \\
\hline & \multirow[b]{2}{*}{ Weekend } & Kota & - & 1 & 1 \\
\hline & & $\begin{array}{l}\text { Luar } \\
\text { Kota }\end{array}$ & 1 & 3 & 4 \\
\hline \multicolumn{2}{|c|}{ Jumlah } & & 7 & 13 & 20 \\
\hline
\end{tabular}

Tabel 6. Jumlah Kecelakaan Pada Simpang Sentot Prawirodirdjo-Simpang Argopuro

\begin{tabular}{|c|c|c|c|c|c|c|c|c|}
\hline \multirow{2}{*}{ Ruas Jalan } & \multirow{2}{*}{$\begin{array}{l}\text { Weekday/ } \\
\text { Weekend }\end{array}$} & \multirow{2}{*}{ Arah } & \multicolumn{5}{|c|}{ Jumlah Kecelakaan } & \multirow{2}{*}{$\sum$ Laka } \\
\hline & & & 2014 & 2015 & 2016 & 2017 & 2018 & \\
\hline \multirow{5}{*}{$\begin{array}{c}\text { Simpang Sentot } \\
\text { Prawirodirdjo- } \\
\text { Simpang } \\
\text { Argopuro }\end{array}$} & \multirow[b]{2}{*}{ Weekday } & Kota & - & - & 1 & 5 & 5 & 11 \\
\hline & & $\begin{array}{l}\text { Luar } \\
\text { Kota }\end{array}$ & 1 & 1 & 3 & 4 & 2 & 11 \\
\hline & \multirow[b]{2}{*}{ Weekend } & Kota & 2 & 1 & - & 1 & 1 & 5 \\
\hline & & $\begin{array}{l}\text { Luar } \\
\text { Kota }\end{array}$ & 4 & 1 & 2 & 1 & 2 & 10 \\
\hline & \multicolumn{2}{|l|}{ Jumlah } & 7 & 3 & 6 & 11 & 10 & 37 \\
\hline
\end{tabular}

Setelah diketahui volume dan jumlah kecelakaan selanjutnya menghitung tingkat kecelakaan. Untuk ruas KFC-Simpang Sentot Prawirodirdjo panjang jalannya adalah 1,4 km dan untuk Simpang Sentot Prawirodirdjo-Simpang Argopuro adalah 0,8 km. Hasil dari perhitungan tingkat kecelakaan dapat dilihat pada tabel berikut. 
Tabel 7. Tingkat Kecelakaan pada ruas KFC-Simpang Sentot Prawirodirdjo

\begin{tabular}{cccccc}
\hline \multirow{2}{*}{ Segmen } & Weekday/ & \multirow{2}{*}{ Arah } & TK, 100 JPKP & TK, 100 JPKP & \multirow{2}{*}{ Rata-Rata } \\
\cline { 4 - 5 } & Weekend & & $\mathbf{2 0 1 7}$ & $\mathbf{2 0 1 8}$ & \\
\hline \multirow{3}{*}{ Weekday } & Kota & 155,43 & 93,26 & 124,34 \\
KFC-Simpang & & Luar Kota & 31,09 & 186,51 & 108,80 \\
Sentot Prawirodirdjo & \multirow{2}{*}{ Weekend } & Kota & 0,00 & 31,09 & 15,54 \\
& & Luar Kota & 31,09 & 93,26 & 62,17 \\
\hline
\end{tabular}

Dari Tabel 7 didapatkan hasil yaitu pada ruas KFC-Simpang Sentot Prawirodirdjo, tingkat kecelakaan tertinggi berada pada weekday arah kota dengan rata-rata tingkat kecelakaan 124,34.

Tabel 8. Tingkat Kecelakaan pada Simpang Sentot Prawirodirdjo-Simpang Argopuro

\begin{tabular}{|c|c|c|c|c|c|c|c|c|}
\hline \multirow[t]{2}{*}{ Segmen } & \multirow{2}{*}{$\begin{array}{l}\text { Weekday/ } \\
\text { Weekend }\end{array}$} & \multirow[t]{2}{*}{ Arah } & $\begin{array}{c}\text { TK, 100 } \\
\text { JPKP }\end{array}$ & $\begin{array}{c}\text { TK, 100 } \\
\text { JPKP }\end{array}$ & $\begin{array}{c}\text { TK, 100 } \\
\text { JPKP }\end{array}$ & $\begin{array}{c}\text { TK, 100 } \\
\text { JPKP }\end{array}$ & $\begin{array}{c}\text { TK, 100 } \\
\text { JPKP }\end{array}$ & \multirow{2}{*}{$\begin{array}{l}\text { Rata- } \\
\text { Rata }\end{array}$} \\
\hline & & & 2014 & 2015 & 2016 & 2017 & 2018 & \\
\hline \multirow{4}{*}{$\begin{array}{c}\text { Simpang } \\
\text { Sentot } \\
\text { Prawirodirdjo- } \\
\text { Simpang } \\
\text { Argopuro }\end{array}$} & \multirow[b]{2}{*}{ Weekday } & Kota & 0,00 & 0,00 & 19,18 & 95,92 & 95,92 & 42,20 \\
\hline & & $\begin{array}{l}\text { Luar } \\
\text { Kota }\end{array}$ & 24,25 & 24,25 & 72,75 & 97,00 & 48,50 & 53,35 \\
\hline & \multirow[b]{2}{*}{ Weekend } & Kota & 46,50 & 23,25 & 0,00 & 23,25 & 23,25 & 23,25 \\
\hline & & $\begin{array}{l}\text { Luar } \\
\text { Kota }\end{array}$ & 91,63 & 22,91 & 45,81 & 22,91 & 45,81 & 45,81 \\
\hline
\end{tabular}

Berdasarkan Tabel 8 didapatkan hasil yaitu tingkat kecelakaan tertinggi berada pada weekday arah luar kota dengan rata-rata tingkat kecelakaan 53,35. Dengan demikian dapat disimpulkan bahwa kedua ruas jalan tersebut yang memiliki tingkat kerawanan kecelakaan paling tinggi yang berada pada arah kota dan luar kota pada waktu weekday atau jam kerja.

\subsection{Karakteristik Kecelakaan}

Dalam penelitian (Herawati, 2014) menjelaskan bahwa karakteristik kecelakaan dikategorikan berdasarkan " $5 \mathrm{~W}+1 \mathrm{H}$ " meliputi kendaraan yang terlibat, korban dan pelaku kecelakaan, faktor penyebab, kecelakaan yang paling sering terjadi, lokasi rawan kecelakaan, dan tipe pergerakan kendaraan. Penelitian (Satiagraha et al., 2009) menjelaskan karakteristik kecelakaan yang paling menonjol meliputi jenis kecelakaan, waktu kejadian kecelakaan, keterlibatan kendaraan, dan korban yang terlibat kecelakaan. Penelitian lain menjelaskan untuk mengetahui karakteristik kecelakaan dengan menggunakan Program SPSS untuk mengetahui hubungan keterkaitan antar variabel kecelakaan, metode analisis statistik yang digunakan yang menghasilkan pengelompokan karakteristik kecelakaan meliputi jenis kecelakaan, faktor pengemudi, profesi pelaku yang sering terlibat kecelakaan, jenis kendaraan, waktu kejadian, dan titik lokasi kecelakaan (Wicaksono et al., 2014). Namun pengelompokan karakteristik kecelakaan pada penelitian ini berdasarkan data IRSMS (Integrated Road Safety Management System) yang didapatkan dari Korlantas Mabes Polri yang dibedakan menjadi:

\section{Korban Kecelakaan}

Korban kecelakaan berdasarkan data IRSMS (Integrated Road Safety Management System) diklasifikasikan seperti pada table 9. Berdasarkan Tabel 9 didapatkan hasil yaitu pada ruas KFCSimpang Sentot Prawirodirdjo klasifikasi korban kecelakaan yang paling banyak untuk weekday $(26,67 \%)$ yaitu kerugian materi arah kota dan weekend $(55,56 \%)$ untuk luka ringan arah luar kota. 
Tabel 9. Klasifikasi Korban Kecelakaan pada ruas KFC-Simpang Sentot Prawirodirdjo

\begin{tabular}{|c|c|c|c|c|c|c|c|c|c|}
\hline \multirow{3}{*}{$\begin{array}{l}\text { Klasifikasi } \\
\text { Korban }\end{array}$} & \multirow{3}{*}{ Arah } & \multicolumn{4}{|c|}{ Weekday } & \multicolumn{4}{|c|}{ Weekend } \\
\hline & & \multirow{2}{*}{$\begin{array}{c}2017 \\
\sum \text { Laka }\end{array}$} & \multirow{2}{*}{$\begin{array}{c}2018 \\
\sum \text { Laka }\end{array}$} & \multirow{2}{*}{ Total } & \multirow{2}{*}{$(\%)$} & \multirow{2}{*}{$\begin{array}{c}2017 \\
\sum \text { Laka }\end{array}$} & \multirow{2}{*}{$\begin{array}{c}2018 \\
\sum \text { Laka }\end{array}$} & \multirow{2}{*}{ Total } & \multirow{2}{*}{$(\%)$} \\
\hline & & & & & & & & & \\
\hline \multirow{2}{*}{$\begin{array}{l}\text { Meninggal } \\
\text { Dunia }\end{array}$} & Kota & 1 & - & 1 & 3,33 & - & - & - & - \\
\hline & Luar Kota & - & - & - & - & - & - & - & - \\
\hline \multirow{2}{*}{ Luka Berat } & Kota & - & - & - & - & - & - & - & - \\
\hline & Luar Kota & - & - & - & - & - & - & - & - \\
\hline \multirow{2}{*}{$\begin{array}{c}\text { Luka } \\
\text { Ringan }\end{array}$} & Kota & 4 & 3 & 7 & 23,33 & - & - & - & - \\
\hline & Luar Kota & 1 & 6 & 7 & 23,33 & 2 & 3 & 5 & 55,56 \\
\hline \multirow{2}{*}{$\begin{array}{l}\text { Kerugian } \\
\text { Materi }\end{array}$} & Kota & 5 & 3 & 8 & 26,67 & - & - & - & - \\
\hline & Luar Kota & 1 & 6 & 7 & 23,33 & 1 & 3 & 4 & 44,44 \\
\hline \multicolumn{2}{|c|}{ Total } & 12 & 18 & 30 & 100 & 2 & 6 & 9 & 100 \\
\hline
\end{tabular}

Tabel 10. Klasifikasi Korban Kecelakaan pada Simpang Sentot Prawirodirdjo-Simpang Argopuro (Weekday)

\begin{tabular}{|c|c|c|c|c|c|c|c|c|}
\hline \multirow{3}{*}{$\begin{array}{l}\text { Klasifikasi } \\
\text { Korban }\end{array}$} & \multirow{3}{*}{ Arah } & \multicolumn{7}{|c|}{ Weekday } \\
\hline & & \multirow{2}{*}{$\begin{array}{c}2014 \\
\sum \text { Laka }\end{array}$} & \multirow{2}{*}{$\begin{array}{c}2015 \\
\sum \text { Laka }\end{array}$} & \multirow{2}{*}{$\begin{array}{c}2016 \\
\sum \text { Laka }\end{array}$} & \multirow{2}{*}{$\begin{array}{c}2017 \\
\sum \text { Laka }\end{array}$} & \multirow{2}{*}{$\begin{array}{c}2018 \\
\sum \text { Laka }\end{array}$} & \multirow{2}{*}{ Total } & \multirow{2}{*}{$(\%)$} \\
\hline & & & & & & & & \\
\hline \multirow{2}{*}{$\begin{array}{l}\text { Meninggal } \\
\text { Dunia }\end{array}$} & Kota & 2 & - & - & - & - & 2 & 3,70 \\
\hline & Luar Kota & 1 & - & - & 1 & 1 & 3 & 5,56 \\
\hline \multirow{2}{*}{ Luka Berat } & Kota & 1 & - & - & - & - & 1 & 1,85 \\
\hline & Luar Kota & - & - & - & - & - & - & - \\
\hline \multirow{2}{*}{$\begin{array}{c}\text { Luka } \\
\text { Ringan }\end{array}$} & Kota & 3 & - & 1 & 7 & 8 & 19 & 35,19 \\
\hline & Luar Kota & - & 1 & 3 & 3 & 1 & 8 & 14,81 \\
\hline \multirow{2}{*}{$\begin{array}{l}\text { Kerugian } \\
\text { Materi }\end{array}$} & Kota & 2 & - & 1 & 3 & 4 & 10 & 18,52 \\
\hline & Luar Kota & 1 & 1 & 3 & 4 & 2 & 11 & 20,37 \\
\hline \multicolumn{2}{|c|}{ Total } & 10 & 2 & 8 & 18 & 16 & 54 & \\
\hline
\end{tabular}

Tabel 11. Klasifikasi Korban Kecelakaan pada Simpang Sentot Prawirodirdjo-Simpang Argopuro (Weekend)

\begin{tabular}{|c|c|c|c|c|c|c|c|c|}
\hline \multirow{3}{*}{$\begin{array}{l}\text { Klasifikasi } \\
\text { Korban }\end{array}$} & \multirow{3}{*}{ Arah } & \multicolumn{7}{|c|}{ Weekend } \\
\hline & & \multirow{2}{*}{$\begin{array}{c}2014 \\
\sum \text { Laka }\end{array}$} & \multirow{2}{*}{$\frac{2015}{\sum \text { Laka }}$} & \multirow{2}{*}{$\begin{array}{c}2016 \\
\sum \text { Laka }\end{array}$} & \multirow{2}{*}{$\begin{array}{c}2017 \\
\sum \text { Laka }\end{array}$} & \multirow{2}{*}{$\frac{2018}{\sum \text { Laka }}$} & \multirow{2}{*}{ Total } & \multirow{2}{*}{$(\%)$} \\
\hline & & & & & & & & \\
\hline \multirow{2}{*}{$\begin{array}{l}\text { Meninggal } \\
\text { Dunia }\end{array}$} & Kota & 1 & - & - & - & - & 1 & 4,55 \\
\hline & Luar Kota & - & - & - & 1 & - & 1 & 4,55 \\
\hline \multirow{2}{*}{ Luka Berat } & Kota & - & - & - & - & - & - & - \\
\hline & Luar Kota & - & - & - & - & - & - & - \\
\hline \multirow{2}{*}{$\begin{array}{c}\text { Luka } \\
\text { Ringan }\end{array}$} & Kota & - & 1 & - & 1 & 1 & 3 & 13,64 \\
\hline & Luar Kota & - & 1 & 2 & - & 2 & 5 & 22,73 \\
\hline \multirow{2}{*}{$\begin{array}{c}\text { Kerugian } \\
\text { Materi }\end{array}$} & Kota & 3 & 1 & - & 1 & 1 & 6 & 27,27 \\
\hline & Luar Kota & - & 1 & 2 & 1 & 2 & 6 & 27,27 \\
\hline \multicolumn{2}{|c|}{ Total } & 4 & 4 & 4 & 4 & 6 & 22 & 100 \\
\hline
\end{tabular}


Tabel 10 didapatkan hasil yaitu korban kecelakaan yang paling banyak adalah untuk Simpang Sentot Prawirodirdjo-Simpang Argopuro adalah weekday $(35,19 \%)$ untuk luka ringan arah kota, dan Tabel 11 didapatkan hasil yaitu weekend $(27,27 \%)$ untuk kerugian materi arah kota dan luar kota.

\section{Tipe Kendaraan}

Tipe kendaraan yang terlibat kecelakaan lalu lintas sangat beragam. Berdasarkan data IRSMS (Integrated Road Safety Management System) beberapa tipe kendaraan yang terlibat kecelakaan diklasifikasikan sebagai berikut.

Tabel 12. Tipe Kendaraan pada ruas KFC-Simpang Sentot Prawirodirdjo

\begin{tabular}{|c|c|c|c|c|c|c|c|c|c|}
\hline \multirow{3}{*}{$\begin{array}{c}\text { Tipe } \\
\text { kendaraan }\end{array}$} & \multirow{3}{*}{ Arah } & \multicolumn{4}{|c|}{ Weekday } & \multicolumn{4}{|c|}{ Weekend } \\
\hline & & 2017 & 2018 & Tatal & $(\%)$ & 2017 & 2018 & Total & $(\%)$ \\
\hline & & Jumlah & Jumlah & 10tal & $(\%)$ & Jumlah & Jumlah & & \\
\hline \multirow{2}{*}{$\begin{array}{l}\text { Sepeda } \\
\text { motor }\end{array}$} & Kota & 7 & 3 & 10 & 35,71 & - & 2 & 2 & 20,00 \\
\hline & $\begin{array}{l}\text { Luar } \\
\text { Kota }\end{array}$ & 2 & 6 & 8 & 28,57 & 2 & 4 & 6 & 60,00 \\
\hline \multirow{2}{*}{$\begin{array}{l}\text { Mobil } \\
\text { Sedan }\end{array}$} & Kota & 1 & - & 1 & 3,57 & - & - & - & - \\
\hline & $\begin{array}{l}\text { Luar } \\
\text { Kota }\end{array}$ & - & 2 & 2 & 7,14 & - & - & - & - \\
\hline \multirow[b]{2}{*}{ Mini Bus } & Kota & - & - & - & - & - & - & - & - \\
\hline & $\begin{array}{l}\text { Luar } \\
\text { Kota }\end{array}$ & - & - & - & - & - & 1 & 1 & 10,00 \\
\hline \multirow{2}{*}{$\begin{array}{l}\text { Pejalan } \\
\text { Kaki }\end{array}$} & Kota & 1 & 1 & 2 & 7,14 & - & - & - & - \\
\hline & $\begin{array}{l}\text { Luar } \\
\text { Kota }\end{array}$ & - & 1 & 1 & 3,57 & - & - & - & - \\
\hline \multirow[b]{2}{*}{ Lain-lain } & Kota & 1 & 1 & 2 & 7,14 & - & - & - & - \\
\hline & $\begin{array}{l}\text { Luar } \\
\text { Kota }\end{array}$ & - & 2 & 2 & 7,14 & - & 1 & 1 & 10,00 \\
\hline Total & & 12 & 16 & 28 & 100 & 2 & 8 & 10 & 100 \\
\hline
\end{tabular}

Berdasarkan Tabel 12, tipe kendaraan yang sering terlibat kecelakaan lalu lintas adalah sepeda motor dengan persentase weekday $(35,71 \%)$ arah kota dan weekend $(60,00 \%)$ arah luar kota.

Tabel 13. Tipe Kendaraan pada Simpang Sentot Prawirodirdjo-Simpang Argopuro (Weekday)

\begin{tabular}{|c|c|c|c|c|c|c|c|c|}
\hline \multirow{2}{*}{$\begin{array}{c}\text { Tipe } \\
\text { kendaraan }\end{array}$} & \multirow{2}{*}{ Arah } & 2014 & 2015 & 2016 & 2017 & 2018 & \multirow{2}{*}{ Total } & \multirow{2}{*}{$(\%)$} \\
\hline & & Jumlah & Jumlah & Jumlah & Jumlah & Jumlah & & \\
\hline \multirow{2}{*}{$\begin{array}{c}\text { Sepeda } \\
\text { motor }\end{array}$} & Kota & 5 & - & 1 & 7 & 8 & 21 & 42,86 \\
\hline & Luar Kota & 2 & 2 & 6 & 4 & 3 & 17 & 34,69 \\
\hline \multirow{2}{*}{ Mobil Sedan } & Kota & - & - & - & 1 & - & 1 & 2,04 \\
\hline & Luar Kota & - & - & - & - & - & - & - \\
\hline \multirow{2}{*}{ Mini Bus } & Kota & - & - & - & 1 & - & 1 & 2,04 \\
\hline & Luar Kota & - & - & - & 1 & - & 1 & 2,04 \\
\hline \multirow{2}{*}{ Pejalan Kaki } & Kota & 2 & - & - & - & 2 & 4 & 8,16 \\
\hline & Luar Kota & - & - & - & 1 & - & 1 & 2,04 \\
\hline \multirow{2}{*}{ Lain-lain } & Kota & 1 & - & - & 1 & 1 & 3 & 6,12 \\
\hline & Luar Kota & - & - & - & - & - & - & - \\
\hline \multicolumn{2}{|c|}{ Total } & 10 & 2 & 7 & 16 & 14 & 49 & 100 \\
\hline
\end{tabular}


Tabel 14. Tipe Kendaraan pada Simpang Sentot Prawirodirdjo-Simpang Argopuro (Weekend)

\begin{tabular}{|c|c|c|c|c|c|c|c|c|}
\hline \multirow{2}{*}{$\begin{array}{c}\text { Tipe } \\
\text { kendaraan }\end{array}$} & \multirow{2}{*}{ Arah } & 2014 & 2015 & 2016 & 2017 & 2018 & \multirow{2}{*}{ Total } & \multirow{2}{*}{$(\%)$} \\
\hline & & Jumlah & Jumlah & Jumlah & Jumlah & Jumlah & & \\
\hline \multirow{2}{*}{$\begin{array}{l}\text { Sepeda } \\
\text { motor }\end{array}$} & Kota & 2 & 2 & - & 2 & - & 6 & 33,33 \\
\hline & Luar Kota & - & 2 & 1 & 2 & 3 & 8 & 44,44 \\
\hline \multirow{2}{*}{ Mobil Sedan } & Kota & - & - & - & - & - & - & - \\
\hline & Luar Kota & - & - & 1 & - & - & 1 & 5,56 \\
\hline \multirow{2}{*}{ Mini Bus } & Kota & - & - & - & - & - & - & - \\
\hline & Luar Kota & - & - & - & - & 1 & 1 & 5,56 \\
\hline \multirow{2}{*}{ Pejalan Kaki } & Kota & - & - & - & - & - & - & - \\
\hline & Luar Kota & - & - & 2 & - & - & 2 & 11,11 \\
\hline \multirow{2}{*}{ Lain-lain } & Kota & - & - & - & - & - & - & - \\
\hline & Luar Kota & - & - & - & - & - & - & - \\
\hline \multicolumn{2}{|c|}{ Total } & 2 & 4 & 4 & 4 & 4 & 18 & 100 \\
\hline
\end{tabular}

Untuk Tabel 13, tipe kendaraan yang sering terlibat kecelakaan lalu lintas di Simpang Sentot Prawirodirdjo-Simpang Argopuro weekday adalah sepeda motor $(42,86 \%)$ arah kota, sedangkan untuk Tabel 14 tipe kendaraan yang sering terlibat kecelakaan adalah weekend dengan persentase $(44,44 \%)$ arah luar kota.

3. Waktu Kejadian Kecelakaan

Waktu terjadinya kecelakaan lalu lintas adalah salah satu identifikasi karakteristik kecelakaan yang penting untuk diketahui terkait dalam tindakan pencegahan kecelakaan lalu lintas. Waktu terjadinya kecelakaan diklasifikasikan sebagai berikut.

Tabel 15. Waktu Kejadian Kecelakaan pada ruas KFC-Simpang Sentot Prawirodirdjo

\begin{tabular}{|c|c|c|c|c|c|c|c|c|c|}
\hline \multirow{3}{*}{$\begin{array}{c}\text { Waktu } \\
\text { Kejadian }\end{array}$} & \multirow{3}{*}{ Arah } & \multicolumn{4}{|c|}{ Weekday } & \multicolumn{4}{|c|}{ Weekday } \\
\hline & & \multirow{2}{*}{\begin{tabular}{|c|}
2017 \\
Jumlah
\end{tabular}} & \multirow{2}{*}{\begin{tabular}{|c|}
2018 \\
Jumlah
\end{tabular}} & \multirow{2}{*}{ Total } & \multirow{2}{*}{$(\%)$} & \multirow{2}{*}{\begin{tabular}{|c|}
2017 \\
Jumlah
\end{tabular}} & \multirow{2}{*}{\begin{tabular}{|c|}
2018 \\
Jumlah
\end{tabular}} & \multirow{2}{*}{ Total } & \multirow{2}{*}{$(\%)$} \\
\hline & & & & & & & & & \\
\hline \multirow{2}{*}{$\begin{array}{c}\text { Dini Hari } \\
(00.01-05.00)\end{array}$} & Kota & 1 & 1 & 2 & 13,33 & - & - & - & - \\
\hline & Luar Kota & - & - & - & - & - & - & - & - \\
\hline \multirow{2}{*}{$\begin{array}{c}\text { Pagi } \\
(05.01-09.00)\end{array}$} & Kota & 1 & - & 1 & 6,67 & - & - & - & - \\
\hline & Luar Kota & - & 2 & 2 & 13,33 & - & 1 & 1 & 20,00 \\
\hline \multirow{2}{*}{$\begin{array}{c}\text { Siang } \\
(09.01-13.00)\end{array}$} & Kota & 1 & - & 1 & 6,67 & - & 1 & 1 & 20,00 \\
\hline & Luar Kota & - & 1 & 1 & 6,67 & - & - & - & - \\
\hline \multirow{2}{*}{$\begin{array}{c}\text { Sore } \\
(13.01-17.00)\end{array}$} & Kota & 1 & - & 1 & 6,67 & - & - & - & - \\
\hline & Luar Kota & 1 & 1 & 2 & 13,33 & - & - & - & - \\
\hline \multirow{2}{*}{$\begin{array}{c}\text { Malam } \\
(17.01-21.00)\end{array}$} & Kota & 1 & 2 & 3 & 20,00 & - & 1 & 1 & 20,00 \\
\hline & Luar Kota & - & 1 & 1 & 6,67 & 1 & 1 & 2 & 40,00 \\
\hline \multirow{2}{*}{$\begin{array}{l}\text { Tengah Malam } \\
(21.01-24.00)\end{array}$} & Kota & - & - & - & - & - & - & - & - \\
\hline & Luar Kota & - & 1 & 1 & 6,67 & - & - & - & - \\
\hline \multicolumn{2}{|c|}{ Total } & 6 & 9 & 15 & 100 & 1 & 4 & 5 & 100 \\
\hline
\end{tabular}

Hasil dari Tabel 15, waktu kejadian kecelakaan pada ruas KFC-Simpang Sentot Prawirodirdjo yang memiliki persentase waktu kejadian paling banyak yaitu malam hari (17.01-21.00) dengan nilai weekday $(20,00 \%)$ arah kota dan weekend $(40,00 \%)$ arah luar kota. 
Tabel 16. Waktu Kejadian Kecelakaan pada Simpang Sentot Prawirodirdjo-Simpang Argopuro (Weekday)

\begin{tabular}{|c|c|c|c|c|c|c|c|c|}
\hline \multirow{2}{*}{$\begin{array}{c}\text { Waktu } \\
\text { Kejadian }\end{array}$} & \multirow{2}{*}{ Arah } & 2014 & 2015 & 2016 & 2017 & 2018 & \multirow{2}{*}{ Total } & \multirow{2}{*}{$(\%)$} \\
\hline & & Jumlah & Jumlah & Jumlah & Jumlah & Jumlah & & \\
\hline \multirow{2}{*}{$\begin{array}{c}\text { Dini Hari } \\
(00.01-05.00)\end{array}$} & Kota & 1 & 1 & 1 & - & - & 3 & 11,11 \\
\hline & Luar Kota & - & - & - & 1 & 1 & 2 & 7,41 \\
\hline \multirow{2}{*}{$\begin{array}{c}\text { Pagi } \\
(05.01-09.00)\end{array}$} & Kota & 1 & - & - & 4 & 1 & 6 & 22,22 \\
\hline & Luar Kota & - & - & - & 2 & 1 & 3 & 11,11 \\
\hline \multirow{2}{*}{$\begin{array}{c}\text { Siang } \\
(09.01-13.00)\end{array}$} & Kota & 1 & - & - & - & 2 & 3 & 11,11 \\
\hline & Luar Kota & - & - & 2 & - & - & 2 & 7,41 \\
\hline \multirow{2}{*}{$\begin{array}{c}\text { Sore } \\
(13.01-17.00)\end{array}$} & Kota & - & - & - & - & - & - & - \\
\hline & Luar Kota & - & - & 1 & - & - & 1 & 3,70 \\
\hline \multirow{2}{*}{$\begin{array}{c}\text { Malam } \\
(17.01-21.00)\end{array}$} & Kota & - & - & - & 1 & - & 1 & 3,70 \\
\hline & Luar Kota & 1 & - & 1 & 1 & - & 3 & 11,11 \\
\hline \multirow{2}{*}{$\begin{array}{l}\text { Tengah Malam } \\
(21.01-24.00)\end{array}$} & Kota & 1 & - & - & - & 1 & 2 & 7,41 \\
\hline & Luar Kota & - & - & - & - & 1 & 1 & 3,70 \\
\hline \multicolumn{2}{|l|}{ Total } & 5 & 1 & 5 & 9 & 7 & 27 & 100 \\
\hline
\end{tabular}

Tabel 17. Waktu Kejadian Kecelakaan pada Simpang Sentot Prawirodirdjo-Simpang Argopuro (Weekend)

\begin{tabular}{|c|c|c|c|c|c|c|c|c|}
\hline \multirow{2}{*}{$\begin{array}{c}\text { Waktu } \\
\text { Kejadian }\end{array}$} & \multirow{2}{*}{ Arah } & 2014 & 2015 & 2016 & 2017 & 2018 & \multirow{2}{*}{ Total } & \multirow{2}{*}{$(\%)$} \\
\hline & & Jumlah & Jumlah & Jumlah & Jumlah & Jumlah & & \\
\hline \multirow{2}{*}{$\begin{array}{c}\text { Dini Hari } \\
(00.01-05.00)\end{array}$} & Kota & - & - & - & - & - & - & - \\
\hline & Luar Kota & - & - & - & - & 2 & 2 & 18,18 \\
\hline \multirow{2}{*}{$\begin{array}{c}\text { Pagi } \\
(05.01-09.00)\end{array}$} & Kota & - & - & - & - & - & - & - \\
\hline & Luar Kota & - & 2 & - & 1 & - & 3 & 27,27 \\
\hline \multirow{2}{*}{$\begin{array}{c}\text { Siang } \\
(09.01-13.00)\end{array}$} & Kota & - & - & - & - & - & - & - \\
\hline & Luar Kota & - & - & - & 1 & 1 & 2 & 18,18 \\
\hline \multirow{2}{*}{$\begin{array}{c}\text { Sore } \\
(13.01-17.00)\end{array}$} & Kota & - & - & - & - & - & - & - \\
\hline & Luar Kota & - & 1 & - & - & - & 1 & 9,09 \\
\hline \multirow{2}{*}{$\begin{array}{c}\text { Malam } \\
(17.01-21.00)\end{array}$} & Kota & 1 & - & - & - & - & 1 & 9,09 \\
\hline & Luar Kota & - & - & 1 & - & - & 1 & 9,09 \\
\hline \multirow{2}{*}{$\begin{array}{l}\text { Tengah Malam } \\
(21.01-24.00)\end{array}$} & Kota & 1 & - & - & - & - & 1 & 9,09 \\
\hline & Luar Kota & - & - & - & - & - & - & - \\
\hline \multicolumn{2}{|l|}{ Total } & 2 & 3 & 1 & 2 & 3 & 11 & 100 \\
\hline
\end{tabular}

Berdasarkan Tabel 16, waktu kejadian kecelakaan pada Simpang Sentot Prawirodirdjo-Simpang Argopuro yang memiliki nilai persentase besar adalah pagi hari (05.01-09.00) dengan nilai weekday $(22,22 \%)$ arah kota dan pada Tabel 17 waktu kejadian kecelakaan dengan persentase besar adalah weekend $(27,27 \%)$ luar kota.

4. Tipe Kecelakaan

Analisis tipe kecelakaan ini bertujuan untuk mengetahui tipe-tipe kecelakaan yang terjadi pada kedua ruas yaitu dapat dilihat pada tabel berikut. 
Tabel 18. Tipe Kecelakaan pada ruas KFC-Simpang Sentot Prawirodirdjo

\begin{tabular}{|c|c|c|c|c|c|c|c|c|c|}
\hline \multirow{3}{*}{$\begin{array}{c}\text { Tipe } \\
\text { Kecelakaan }\end{array}$} & \multirow{3}{*}{ Arah } & \multicolumn{4}{|c|}{ Weekday } & \multicolumn{4}{|c|}{ Weekday } \\
\hline & & \multirow{2}{*}{\begin{tabular}{|c|}
2017 \\
Jumlah
\end{tabular}} & \multirow{2}{*}{\begin{tabular}{|c|}
2018 \\
Jumlah
\end{tabular}} & \multirow{2}{*}{ Total } & \multirow{2}{*}{$(\%)$} & \multirow{2}{*}{$\begin{array}{c}2017 \\
\text { Jumlah }\end{array}$} & \multirow{2}{*}{\begin{tabular}{|c|}
2018 \\
Jumlah
\end{tabular}} & \multirow{2}{*}{ Total } & \multirow{2}{*}{$(\%)$} \\
\hline & & & & & & & & & \\
\hline \multirow{2}{*}{$\begin{array}{l}\text { Di ruas jalan, } \\
\text { pejalan kaki } \\
\text { menyebrang } \\
\text { dari kiri ke } \\
\text { kanan }\end{array}$} & Kota & - & 1 & 1 & 10,00 & - & - & - & - \\
\hline & Luar Kota & - & 1 & 1 & 10,00 & - & - & - & - \\
\hline & Kota & 3 & - & 3 & 30,00 & - & - & - & - \\
\hline $\begin{array}{l}\text { Tabrakan saat } \\
\text { menyalip dari } \\
\text { kanan }\end{array}$ & Luar Kota & - & 1 & 1 & 10,00 & 1 & 1 & 2 & 50,00 \\
\hline \multirow{2}{*}{$\begin{array}{l}\text { Tabrakan saat } \\
\text { menyalip dari } \\
\text { kiri }\end{array}$} & Kota & - & - & - & - & - & - & - & - \\
\hline & Luar Kota & - & 1 & 1 & 10,00 & - & - & - & - \\
\hline \multirow{2}{*}{$\begin{array}{c}\text { Tabrakan } \\
\text { depan- } \\
\text { belakang }\end{array}$} & Kota & - & 1 & 1 & 10,00 & - & - & - & - \\
\hline & Luar Kota & - & 2 & 2 & 20,00 & - & 1 & 1 & 25,00 \\
\hline \multirow{2}{*}{$\begin{array}{l}\text { Tabrakan saat } \\
\text { pindah lajur } \\
\text { ke kiri }\end{array}$} & Kota & - & - & - & - & - & - & - & - \\
\hline & Luar Kota & - & - & - & - & - & 1 & 1 & 25,00 \\
\hline \multicolumn{2}{|c|}{ Total } & 3 & 7 & 10 & 100 & 1 & 3 & 4 & 100 \\
\hline
\end{tabular}

Berdasarkan Tabel 18, tipe kecelakaan yang sering terjadi di ruas KFC-Simpang Sentot Prawirodirdjo adalah "tabrakan saat menyalip dari kanan" dengan persentase weekday $(30,00 \%)$ arah kota dan weekend $(50,00 \%)$ arah luar kota.

Tabel 19. Tipe Kecelakaan pada Simpang Sentot Prawirodirdjo-Simpang Argopuro (Weekday)

\begin{tabular}{|c|c|c|c|c|c|c|c|c|}
\hline \multirow{2}{*}{ Tipe Kecelakaan } & \multirow{2}{*}{ Arah } & 2014 & 2015 & 2016 & 2017 & 2018 & \multirow{2}{*}{ Total } & \multirow{2}{*}{$(\%)$} \\
\hline & & Jumlah & Jumlah & Jumlah & Jumlah & Jumlah & & \\
\hline \multirow{2}{*}{$\begin{array}{l}\text { Di ruas jalan, pejalan } \\
\text { kaki menyebrang dari } \\
\text { kiri ke kanan }\end{array}$} & Kota & - & - & - & - & 1 & 1 & 6,67 \\
\hline & Luar Kota & - & - & - & 1 & - & 1 & 6,67 \\
\hline \multirow{2}{*}{$\begin{array}{c}\text { Tabrakan saat } \\
\text { menyalip dari kanan }\end{array}$} & Kota & 1 & - & - & 1 & - & 2 & 13,33 \\
\hline & Luar Kota & - & 1 & 1 & 2 & - & 4 & 26,67 \\
\hline \multirow{2}{*}{$\begin{array}{l}\text { Tabrakan depan- } \\
\text { belakang }\end{array}$} & Kota & 1 & - & - & 1 & 1 & 3 & 20,00 \\
\hline & Luar Kota & - & - & 1 & - & - & 1 & 6,67 \\
\hline \multirow{2}{*}{$\begin{array}{l}\text { Tabrakan saat pindah } \\
\text { lajur ke kanan }\end{array}$} & Kota & - & - & - & - & 1 & 1 & 6,67 \\
\hline & Luar Kota & - & - & - & - & - & - & - \\
\hline \multirow{2}{*}{$\begin{array}{l}\text { Tabrakan saat pindah } \\
\text { lajur ke kiri }\end{array}$} & Kota & - & - & - & 1 & - & 1 & 6,67 \\
\hline & Luar Kota & - & - & - & 1 & - & 1 & 6,67 \\
\hline Total & & 2 & 1 & 2 & 7 & 3 & 15 & 100 \\
\hline
\end{tabular}

Tabel 19 menunjukkan bahwa tipe kecelakaan pada Simpang Sentot Prawirodirdjo-Simpang Argopuro yang sering terjadi adalah "tabrakan saat menyalip dari kanan dengan persentase weekday $(26,67 \%)$ arah luar kota dan Tabel 20 menunjukkan tipe kecelakaan yang memiliki persentase besar yaitu weekend $(42,86 \%)$ arah kota. 
Tabel 20. Tipe Kecelakaan pada Simpang Sentot Prawirodirdjo-Simpang Argopuro (Weekend)

\begin{tabular}{|c|c|c|c|c|c|c|c|c|}
\hline \multirow{2}{*}{ Tipe Kecelakaan } & \multirow{2}{*}{ Arah } & 2014 & 2015 & 2016 & 2017 & 2018 & \multirow{2}{*}{ Total } & \multirow{2}{*}{$(\%)$} \\
\hline & & Jumlah & Jumlah & Jumlah & Jumlah & Jumlah & & \\
\hline $\begin{array}{l}\text { Di ruas jalan, } \\
\text { pejalan kaki }\end{array}$ & Kota & - & - & - & - & - & - & - \\
\hline $\begin{array}{c}\text { menyebrang dari } \\
\text { kiri ke kanan }\end{array}$ & Luar Kota & - & - & 2 & - & - & 2 & 28,57 \\
\hline \multirow{2}{*}{$\begin{array}{c}\text { Tabrakan saat } \\
\text { menyalip dari kanan }\end{array}$} & Kota & - & 2 & - & - & 1 & 3 & 42,86 \\
\hline & Luar Kota & - & - & - & - & - & - & - \\
\hline \multirow{2}{*}{$\begin{array}{l}\text { Tabrakan depan- } \\
\text { belakang }\end{array}$} & Kota & - & - & - & - & - & - & - \\
\hline & Luar Kota & - & - & - & - & 1 & 1 & 14,29 \\
\hline \multirow{2}{*}{$\begin{array}{c}\text { Tabrakan saat } \\
\text { pindah lajur ke } \\
\text { kanan }\end{array}$} & Kota & - & - & - & - & - & - & - \\
\hline & Luar Kota & - & - & - & - & 1 & 1 & 14,29 \\
\hline \multirow{2}{*}{$\begin{array}{c}\text { Tabrakan saat } \\
\text { pindah lajur ke kiri }\end{array}$} & Kota & - & - & - & - & - & - & - \\
\hline & Luar Kota & - & - & - & - & - & - & - \\
\hline Total & & 0 & 2 & 2 & 0 & 3 & 7 & 100 \\
\hline
\end{tabular}

\section{Kesimpulan}

Berdasarkan hasil dan pembahasan yang telah dipaparkan, dapat disimpulkan bahwa nilai EAN pada ruas KFC-Simpang Sentot Prawirodirdjo dengan persentase terbesar yaitu weekday arah kota (47,13\%), sedangkan pada Simpang Sentot Prawirodirdjo-Simpang Argopuro yang memiliki persentase terbesar yaitu weekday arah kota (42,54\%). Tingkat kecelakaan pada ruas KFC-Simpang Sentot Prawirodirdjo yang memiliki nilai rata-rata tertinggi yaitu weekday arah kota dengan ratarata tingkat kecelakaan 124,34 dan untuk tingkat kecelakaan pada Simpang Sentot PrawirodirdjoSimpang Argopuro dengan nilai rata-rata tertinggi yaitu pada weekday arah luar kota dengan ratarata tingkat kecelakaan 53,35. Karakteristik kecelakaan berdasarkan data IRSMS (Integrated Road Safety Management System) dibedakan atas korban kecelakaan, tipe kendaraan, waktu kejadian kecelakaan, dan tipe kecelakaan. Berdasarkan korban kecelakaan pada ruas KFC-Simpang Sentot Prawirodirdjo yang paling banyak adalah luka ringan dan kerugian materi yaitu weekday $(26,67 \%)$ dan weekend $(55,56 \%)$. Tipe Kendaraan yang sering terlibat kecelakaan lalu lintas yaitu sepeda motor dengan persentase weekday $(35,71 \%)$ dan weekend $(60,00 \%)$. Waktu kejadian kecelakaan yang sering terjadi adalah malam hari dengan persentase weekday $(20,00 \%)$ dan weekend $(40,00 \%)$. Tipe kecelakaan yang mendominasi adalah tabrakan saat menyalip dari kanan yaitu weekday $(30,00 \%)$ dan weekend $(50,00 \%)$. Untuk Simpang Sentot Prawirodirdjo-Simpang Argopuro korban kecelakaan yang paling banyak adalah luka ringan dan kerugian materi yaitu weekday $(35,19 \%)$ dan weekend $(27,27 \%)$. Kendaraan yang sering terlibat kecelakaan adalah sepeda motor dengan persentase weekday $(42,86 \%)$ dan weekend $(44,44 \%)$. Waktu kejadian yang menjadi sering terjadinya kecelakaan yaitu pagi hari dengan persentase weekday $(22,22 \%)$ dan weekend $(27,27 \%)$. Tipe kecelakaan yang sering terjadi yaitu tabrakan saat menyalip dari kanan dengan persentase weekday $(26,67 \%)$ dan weekend $(42,86 \%)$. 


\section{Daftar Pustaka}

Arifin, M., Wicaksono, A., \& Sulistyono, S. (2019). Motorcycle Accident Probability Based on Characteristics of Socio-Economic, Movement and Behaviors in Surabaya City. Advances in Engineering Research, 186(Apte 2018), 159-163.

Carina, F. (2014). Analisis Karakteristik Kecelakaan Dan Penanganan Lokasi Rawan Kecelakaan Lalu Lintas Di Kota Lubuklinggau. Jurnal Penelitian Dan Kajian Teknik Sipil, 5, 24-31.

Departemen Permukiman dan Prasarana Wilayah. (2004). Penanganan Lokasi Rawan Kecelakaan Lalu Lintas. Jakarta, 54.

Direktorat Keselamatan Transportasi Darat. (2007). Pedoman Operasi Accident Blackspot Investigation Unit / Unit Penelitian Kecelakaan Lalu Lintas (ABIU/UPK). Jakarta.

Feryanti, I. K. (2019). Analisis Kecelakaan Lalu Lintas Di Kota Surakarta.

Hayati, N. N., Sulistyono, S., \& Wijaya, J. S. M. (2016). Identifikasi Karakteristik dan Lokasi Rawan Kecelakaan Lalu Lintas pada Jalur Pantura Surabaya - Tuban. Seminar Nasional Teknik Sipil, March 2012, 251-261.

Herawati. (2014). Karakteristik Dan Penyebab Kecelakaan Lalu Lintas Di Indonesia Tahun 2012. Warta Penelitian Perhubungan, 26(3), 133-142.

Indriastuti, A. K., Fauziah, Y., \& Priyanto, E. (2011). Karakteristik Kecelakaan dan Audit Keselamatan Jalan pada Ruas Ahmad Yani Surabaya. Jurnal Rekayasa Sipil, 5(1), 40-44.

Kriswardhana, W., Supriyanto, D., Mujanarko, S. W., Sulistyono, S., Hayati, N. N., Ramadhani, R. A., Ervina, I., \& Wicaksono, A. (2019). Modeling The Probability Of Speeding Behaviour And Accident Involvement Using Binary Logistic Regression In East Java Province. Journal of Indonesia Road Safety, 2(3), 149-158.

Satiagraha, A., Sulistyono, S., \& S, J. W. (2009). Analisis Karakteristik Kecelakaan Lalu Lintas Segmen Jalan Jember - Sumberbaru (KM JBR. 7 - KM JBR. 38). Simposium Nasional FSTPT XII, 1380-1391.

Sugiyanto, G. (2010). Biaya Kecelakaan Lalulintas Jalan di Indonesia dan Vietnam. Jurnal Transportasi, 10(2), 135-148.

Sugiyanto, G., Mulyono, B., \& Santi, M. Y. (2014). Karakteristik Kecelakaan Lalu Lintas Dan Lokasi Black Spot Di Kabupaten Cilacap. Jurnal Teknik Sipil, 12(4), 259-266.

Sugiyanto, G., \& Santi, M. Y. (2015). Karakteristik Kecelakaan Lalu Lintas dan Pendidikan Keselamatan Berlalulintas Sejak Usia Dini: Studi Kasus di Kabupaten Purbalingga. Jurnal Ilmiah Semesta Teknika, 18(1), 65-75.

Wicaksono, D., Fathurochman, R. A., Riyanto, B., \& Wicaksono. (2014). Analisis Kecelakaan Lalu Lintas (Studi Kasus-Jalan Raya Ungaran-Bawen). Jurnal Karya Teknik Sipl, 3(2), 345-355.

Zanuardi, A., \& Suprayitno, H. (2018). Analisa Karakteristik Kecelakaan Lalu Lintas di Jalan Ahmad Yani Surabaya melalui Pendekatan Knowledge Discovery in Database. Jurnal Manajemen Aset Infrastruktur \& Fasilitas, 2(1), 45-55. 